\title{
Alterations in leaf anatomy and physiology caused by the red mite (Oligonychus ilicis) in plants of Coffea arabica
}

\author{
Joel I. Fahl ${ }^{1 *}$, Rachel B. Queiroz-Voltan², Maria Luiza C. Carelli' ${ }^{1}$, Marlene A. Schiavinato ${ }^{3}$, \\ Ana K. S. Prado ${ }^{1}$ and Júlio C. Souza ${ }^{4}$
}

${ }^{1}$ Centro de Pesquisa e Desenvolvimento de Ecofisiologia e Biofísica, Instituto Agronômico, CP 28, $13012-970$ Campinas, SP, Brasil. ${ }^{2}$ Núcleo de Pesquisa e Desenvolvimento do Jardim Botânico, Instituto Agronômico, CP 28, 13012-970 Campinas, SP, Brasil. ${ }^{3}$ Departamento de Fisiologia Vegetal, Instituto de Biologia, UNICAMP, CP 6109, 13083-970, Campinas, SP, Brasil. ${ }^{4}$ EPAMIG-CTSM-EcoCentro, CP 176, 37200-000 Lavras, MG, Brasil. *Corresponding author:fahl@iac.sp.gov.br

Received: 15 December 2006; Returned for revision: 26 March 2007; Accepted: 15 June 2007

Three degrees of red mite infestation (Oligonychus ilicis McGregor) (Acari: Tetranychidae) were evaluated with regard to leaf anatomy, photosynthetic gas exchange and leaf ethylene production, in a commercial crop of approximately 12 year-old trees of Coffea arabica 'Catuaí Vermelho'. As a complementary study, foliar anatomy was also evaluated in a recuperated crop of $C$. arabica 'Mundo Novo' that had presented a high degree of red mite infestation during the dry period of the prior growing season. The red mite-infested leaves were bronze-coloured, with intensity proportional to the degree of internal damage. On feeding, the red mite introduces its stylet in the adaxial epidermis and, as a result, chloroplasts are destroyed in the feeding area. The number of chlorophyll-free cells in the palisade parenchyma was proportional to the intensity of attack by red mites. The cells of the spongy parenchyma, localized below the feeding areas of the mites, did not show any alterations, having intact chloroplasts, with the exception of some leaves that suffered from intense attack. Net photosynthesis rate declined, but only in leaves under intense red mite attack, due to destruction of chloroplasts in the attacked cells. Nevertheless, transpiration and stomatal conductance were unaffected by red mite. The concentrations of ethylene produced by the leaves were similar regardless of three levels of attack, suggesting that red mite infestation does not lead to leaf abscission. In addition, anatomical studies of 'Mundo Novo' leaves of plants that visually recovered from red mite attack showed that, even with scars present, they continued attached on the plant.

Key words: coffee, ethylene, leaf structure damage, photosynthetic gas exchange

\begin{abstract}
Alterações na anatomia foliar e fisiologia causadas pelo ácaro-vermelho (Oligonychus ilicis) em plantas de Coffea arabica: Foram avaliados os efeitos de três graus de infestação por ácaro-vermelho (Oligonychus ilicis McGregor) (Acari: Tetranychidae) na anatomia foliar, nas trocas gasosas fotossintéticas e na produção de etileno pelas folhas, em uma cultura comercial de Coffea arabica 'Catuaí Vermelho', de aproximadamente 12 anos de idade. Em estudo complementar, também foi avaliada a anatomia foliar em uma cultura de C. arabica 'Mundo Novo', recuperada de intensa infestação de ácaro-vermelho durante o período seco da estação de crescimento anterior. As folhas infestadas pelo ácaro-vermelho apresentaram uma coloração "bronzeada", de intensidade proporcional ao grau de dano interno. Ao se alimentar, o ácaro-vermelho introduz seu estilete na epiderme adaxial e, em conseqüência, há destruição dos cloroplastos na área restrita onde ocorre a alimentação. O número de células aclorofiladas no parênquima paliçádico foi proporcional à intensidade do ataque do ácaro-vermelho. As células do parênquima esponjoso, localizadas abaixo das regiões de alimentação do ácaro, apresentaram-se inalteradas, com seus cloroplastos intactos, com exceção de algumas folhas intensamente atacadas. A taxa de fotossíntese líquida decresceu apenas nas folhas com ataque intenso do ácarovermelho, devido à destruição dos cloroplastos nas células atacadas. Contudo, a transpiração e a condutância
\end{abstract}


estomática não foram alteradas pelo ataque do ácaro-vermelho. Não houve diferença entre as concentrações de etileno liberadas pelas folhas nas três intensidades de infestação do ácaro, sugerindo que seu ataque não ocasiona abscisão foliar. Em adição, os estudos anatômicos das folhas de plantas de 'Mundo Novo', externamente recuperadas do ataque do ácaro-vermelho, mostraram que, apesar das lesões cicatrizadas, permaneceram na planta.

Palavras-chaves: café, danos estruturais na folha, etileno, trocas gasosas fotossintéticas

\section{INTRODUCTION}

The first evidence for the occurrence of the red mite (Oligonychus ilicis McGregor) (Acari: Tetranychidae) in coffee plants date back to the 1950s when it was wrongly reported as another species (Amaral, 1951). The red mite lives on the upper surface of coffee leaves, on which the females spin delicate webs and lay their eggs. These need a humid environment for their development and, at the same time, porous surroundings in order to maintain gas exchange. In consequence, waste and dust collect on the leaves and they lose their characteristic shine becoming bronze-coloured, which is the main external symptom of red mite infestation of the coffee plant (Flechtmann, 1979).

In order to feed itself the red mite introduces its stylet into the plant tissue and removes part of the cellular contents. The chloroplasts of the affected cells become degraded leading to the appearance of chlorotic areas (Flechtman, 1979). In the case of some tetranychid mites which infest other plant species, it has been observed that photosynthesis of the infested leaves is inhibited, while transpiration is accelerated, leading to the drying out and premature fall of the leaves (Flechtman, 1979). However, in the available literature there is no information regarding the effects of the red mite on the coffee tree.

The greatest incidence of red mites occurs in the Brazilian states of São Paulo and Minas Gerais in the dry season (winter). Rain results in a natural control of the mite, since being localized on the upper surface of the leaf, they are easily washed off by water. The red mite has been reported as the second most important pest of robusta coffee (C. canephora 'Conilon'), considered to be more sensitive than C. arabica (Reis et al., 2004).

The intensive use of copper fungicides to combat a leaf rust (Hemileia vastatrix) (Paulini, 1975; Reis and Teodoro, 2000) and the application of insecticides of the pyrethroid group for the control of the leaf miner Perileucoptera coffeella (Ferreira et al., 1980; Paulini et al., 1980), lead to a significant increase in the red mite population of the coffee plant. This population increase has been correlated with the increased reproductive potential of the mite that might be associated with the improved nutritional conditions of the plants through the use of pesticides and the action of these on the natural enemies of the mites (Huffaker et al., 1969; Reis and Souza, 1986; Reis and Teodoro, 2000).

It has been reported that an intensive red mite attack can cause defoliation, leading to enormous damage to coffee crops. Leaf abscission can be triggered by a range of conditions, including excessive water loss and mechanical injury (Blundell and Peart, 2000; Cheong et al., 2002). In damaged plant tissues there is an induction of ethylene biosynthesis that, in turn, has been associated with the induction and acceleration of abscission (Brown, 1997; Taiz and Zeiger, 1998; Wang et al., 2002). For this reason, it would be important to verify the effect of damages caused by the red mite on ethylene production of coffee plant.

Aiming for a better understanding of the damages caused by red mites to the coffee crop, we evaluated the effect of different intensities of leaf infestation by red mites on leaf anatomy, photosynthetic gas exchange and the production of ethylene.

\section{MATERIAL AND METHODS}

Plant material and growth conditions: The study was carried out in the agricultural year 2005-2006 at Garça (22 ${ }^{\circ} 10^{\prime}$ S , 49 $9^{\circ} 33^{\prime}$ W, 657 m a.s.1.), State of São Paulo, Brazil, on 12-year-old non-irrigated C. arabica 'Catuaí' plants, grown in an abrupt eutrophic Podzol, and spaced $4 \mathrm{~m}$ by $1 \mathrm{~m}$ apart. The plants received the following phytosanitary treatments: Actara $300 \mathrm{WG}$ (Thiametoxan $300 \mathrm{~g} \mathrm{~kg}^{-1}$ ) $1.4 \mathrm{~kg} \mathrm{ha}^{-1}$ (November 2005); Amistar (Azoxytrobin $200 \mathrm{~g} \mathrm{~L}^{-1}$ ) $0.1 \mathrm{~kg} \mathrm{ha}^{-1}$ (December 2005 and February 2006) and Recop 500 PM (copper oxychloride $50 \%) 2.0 \mathrm{~kg} \mathrm{ha}^{-1}$ (January and March 2006). Ten plants in close proximity with different degrees of red mite $(O$. 
ilicis) infestation were selected: degree 1 (D1) - leaves apparently healthy; degree 2 (D2) - leaves with up to $50 \%$ of the upper leaf surface with a bronze-coloured aspect; and degree 3 (D3) leaves with 51 to $100 \%$ of the leaf surface bronze-coloured, as shown in Figure 1.

As a complementary study, foliar anatomy (see below) was also evaluated in a recuperated crop of $C$. arabica 'Mundo Novo' that had presented a high degree of red mite infestation during the dry period of the 2004-2005 growing season. This crop had received, in that season, applications of: Verdadero 20 GR (Cyproconazole $100 \mathrm{~g}$ $\mathrm{kg}^{-1}$ + Thiametoxan $100 \mathrm{~g} \mathrm{~kg}^{-1}$ ) $30 \mathrm{~kg} \mathrm{ha}^{-1}$ (November 2004); Amistar (Azoxytrobin $250 \mathrm{~g} \mathrm{~L}^{-1}$ ) $0.1 \mathrm{~kg} \mathrm{ha}^{-1}$ (December 2004 and February 2005); Recop 500 PM (50\% copper oxychloride) $3 \mathrm{~kg} \mathrm{ha}^{-1}$ (January and March 2005); Omite $720 \mathrm{CE}$ (720 g L-1 Progargit) $0.5 \mathrm{~L} \mathrm{ha}^{-1}$ (February 2005). In the following year the crop received: Verdadero $600 \mathrm{WG}$ (Cyproconazole $300 \mathrm{~g} \mathrm{~kg}^{-1}+$ Thiametoxan $300 \mathrm{~g} \mathrm{~kg}^{-1}$ ) $1 \mathrm{~kg}$ $\mathrm{ha}^{-1}$ (November 2005); Amistar (Azoxytrobin $250 \mathrm{~g} \mathrm{~L}^{-1}$ ) 0.1 $\mathrm{kg} \mathrm{ha}^{-1}$ (December 2005 and February 2006); Recop 500 PM (copper oxychloride 50\%) $3 \mathrm{~kg} \mathrm{ha}^{-1}$ (January and March 2006); Vertimec 18 CE (Abamectin $18 \mathrm{~g} \mathrm{~L}^{-1}$ ) $0.4 \mathrm{~L} \mathrm{ha}^{-1}$ (February 2006); Priori Xtra (Cyproconazole $80 \mathrm{~g} \mathrm{~kg}^{-1}+$ Azoxytrobin $250 \mathrm{~g} \mathrm{~L}^{-1}$ ) $0.5 \mathrm{~L} \mathrm{ha}^{-1}$ (March 2006) and Alto $100 \mathrm{CE}$ (Cyproconazole $100 \mathrm{~g} \mathrm{~L}^{-1}$ ) $0.25 \mathrm{~L} \mathrm{ha}^{-1}$; Vertimec 18 CE (Abamectin $18 \mathrm{~g} \mathrm{~L}^{-1}$ ) $0.4 \mathrm{~L} \mathrm{ha}^{-1}$ (April 2006).

Unless otherwise indicated, sampling and measurements were made using leaves from $C$. arabica 'Catuaí'.

Anatomical analyses: Anatomical studies were carried out on five samples of leaves, similar to those used for gas exchange measurements, collected from five 'Catuaí' plants in the above described crop. The sample comprised of expanded, non-senescent leaves of the 2 nd or 3rd pair, counting from the apex of the plagiotropic branch located in the mid-region of the plant. Segments of $0.25 \mathrm{~cm}^{2}$ were removed from each leaf, in the mid-region of the blade next to the vein, from bronze-coloured (infestation degrees 2 and 3 ) and non-bronze-coloured areas (degree 1). They were then fixed in $50 \%$ F.A.A. (formaldehyde-acetic acid-ethyl alcohol) (Johansen, 1940), placed under vacuum for $48 \mathrm{~h}$ followed by dehydration of the portions of interest in an ethyl alcohol series, embedded in paraffin and sectioned transversely with a rotating microtome. The $10 \mu \mathrm{m}$ thick sections were stained with alcian blue-safranin, as described in Gabrielli (1992). The chlorotic areas observed in the palisade parenchyma were quantified using 20 samples for each level of damage, and the means compared using the Tukey test $(P<0.05)$. The slides were observed under a Leica optical microscope (Leica DML B, Wetzlar, Germany) coupled to a photographic camera.

Physiological analyses: The measurements of net photosynthesis $(A)$, stomatal conductance $\left(g_{\mathrm{s}}\right)$ and transpiration rate $(E)$ were carried out in the field using a portable system for analysing photosynthetic gas exchange (LI-6400, Li-Cor., Lincoln, USA). All measurements were made on the third leaf pair of the plagiotropic branch, counting from the apex to the base. The data were collected on the $16^{\text {th }}$ of June 2006, between $0900 \mathrm{~h}$ and $1130 \mathrm{~h}$, using two leaves on each plant (20 plants) for each degree of infestation, totalling 60 measurements. At the time of measurements the average of each of the environmental variables was: temperature, $32^{\circ} \mathrm{C}$; irradiance, $1750 \mu \mathrm{mol} \mathrm{m} \mathrm{m}^{-2} \mathrm{~s}^{-1}$; atmospheric $\mathrm{CO}_{2}$ partial pressure, $38 \mathrm{~Pa}$; and leaf-to-air vapour pressure difference, $4.5 \mathrm{kPa}$.

The concentration of liberated ethylene was determined on five samples of ten leaves, for each degree of infestation, placed in hermetic flasks of $280 \mathrm{~mL}$. The analyses were carried out using a gas chromatograph (GC-14B, Shimadzu, Kyoto, Japan), fitted with a flameionization detector and a $1.5 \mathrm{~m}$ by $1 / 8$ inch stainless steel column of Hayesep T. Nitrogen was used as carrier gas at

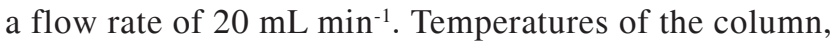
injector and detector were respectively $80^{\circ} \mathrm{C}, 100^{\circ} \mathrm{C}$ and $150^{\circ} \mathrm{C}$. Pure ethylene (White Martins, São Paulo, Brazil) was used as standard. The data for ethylene evolution over a $24 \mathrm{~h}$ period were expressed in $\mathrm{nmol} \mathrm{g}^{-1} \mathrm{FW}$.

\section{RESULTS AND DISCUSSION}

\section{Leaf anatomy}

External structure: Leaves infested with the red mite were bronze-coloured (Figure 1), with colour intensity proportional to the level of internal damage. According to Flechtman (1979) the females spin webs on the surface where they lay their eggs. These need a humid environment for their development and, at the same time, 

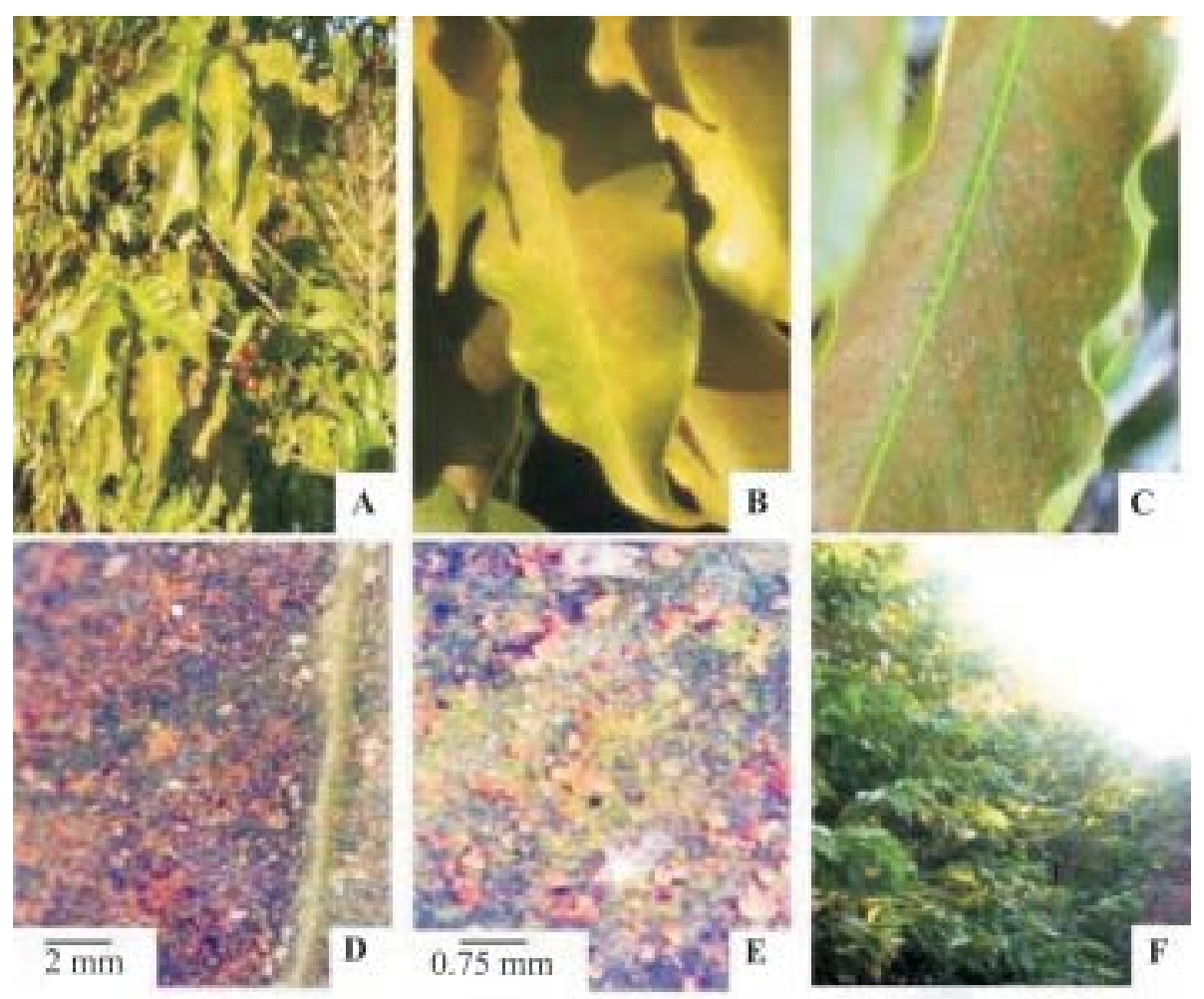

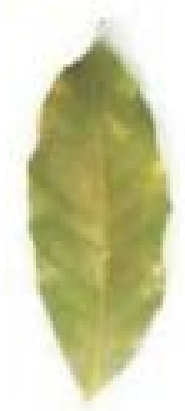

1

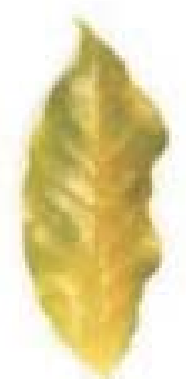

2

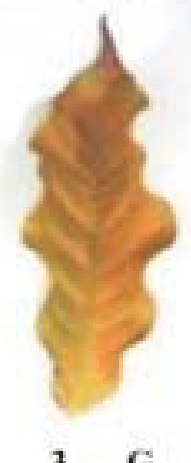

3 G

Figure 1. General aspect of Coffea arabica 'Catuaí' plants with leaves showing different degrees of symptoms of red mite infestation (A); detail of leaves with symptoms (B-C); adaxial surface of the leaf blade with grains of sand, eggs and shed cuticles of mites (D-E); recuperated C. arabica 'Mundo Novo' plants that had presented high degree of red mite infestation during the prior growing season (2004-2005) (F); leaves with all three degrees of symptoms (G).

porous surroundings in order to maintain gas exchange. Since infestation occurs predominantly in hot and dry spells, this microclimate favours the accumulation of dust and sand particles, leaving the leaves with a dull and dusty aspect (Figures 1 and 2). Figure 2 shows the three categories of symptoms for comparison as well as the leaves of plants treated in 2005 and recovered in 2006. The leaves apparently not infested present the lowest signs of mite infestation. Since during the process of slide preparation the tissue goes through dehydration and hydration processes in ethyl alcohol solutions, the debris is probably removed from the cuticle surface (tissue that covers the epidermis).

Internal Structure: The anatomy of healthy leaves of cultivars used in this study, namely 'Catuaí' and 'Mundo Novo', is similar to that of C. arabica L. var. typica Cramer, described previously by Dedecca (1957) as well 


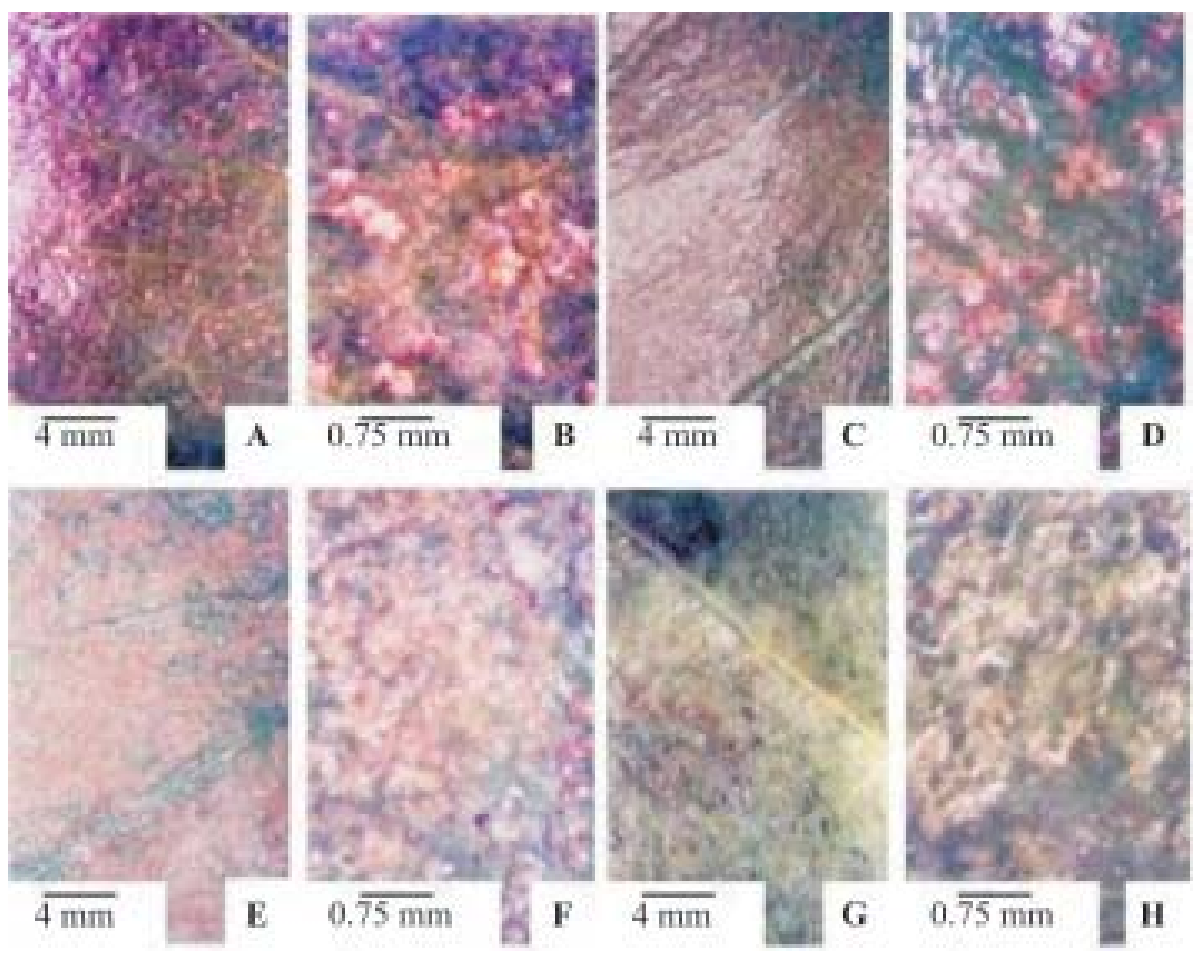

Figure 2. Adaxial surface of leaf blade of Coffea arabica 'Catuaí' showing symptoms of red mite infestation: degree 1 (AB); degree 2 (C-D); and degree 3 (E-F). Recuperated $C$. arabica 'Mundo Novo' plants that had presented a high degree of red mite infestation during the prior growing season (2004-2005) are also shown (G-H).

as other cultivars described by Voltan et al. (1992), Carvalho et al. (2001) and Morais et al. (2004). As shown in Figure $3 \mathrm{~A}$, leaves of the coffee plant are dorsiventral, that is, have a palisade parenchyma localized on the upper face of the blade (adaxial) and a spongy parenchyma on the lower face (abaxial). The palisade parenchyma is made up of elongated cells, densely packed and arranged perpendicularly to the epidermis. The spongy parenchyma cells show different forms and constitute the major part of the mesophyll with 8-10 layers of cells arranged in an irregular fashion, with a smaller number of chloroplasts compared to the palisade cells, as well as large intercellular spaces. The abaxial epidermis cells contain the stomata and are smaller than those of the adaxial epidermis.

The leaves of 'Catuaí' showing degree 1 severity of red mite infestation are anatomically similar to healthy coffee leaves (Figure 3A). It may be seen that the epidermal cells and the chloroplasts of these leaves are intact, whereas in leaves with degrees 2 and 3 severity of red mite infestation there was partial destruction of the chloroplasts, especially in the palisade parenchyma region (Figure 3B-D) and, seldom, in the spongy parenchyma of leaves with degree 3 symptoms. The increase of damage level caused by the red mite was proportional to the percent chlorotic area (Table 1). The stylet of $O$. ilicis penetrates the adaxial epidermis, reaching the palisade layer. They feed themselves on the cell contents, destroying the chloroplasts in the area restricted to where feeding took place. The mouthparts ("lips") of these mites adjust to the leaf surface, forming a structure similar to a suction cap that permits the suction of the cell contents with the aid of the vacuum produced by the pharynx (Flechtmann, 1979). The remaining cell content in the feeding region forms an amorphous mass, which is stained by safranin in the slides (Figures 3B-E). The leaves with degree 2 symptoms show a smaller number of cells devoid of chlorophyll in the palisade parenchyma than in degree 3 and, in the latter the presence of abnormal cell division was observed in the feeding region, often with deposits of lignin in the cell walls, forming a scar tissue. The cells of the spongy parenchyma, localized below the feeding regions of the mites, normally appear unaltered, with intact chloroplasts (Figure 3C-D). 


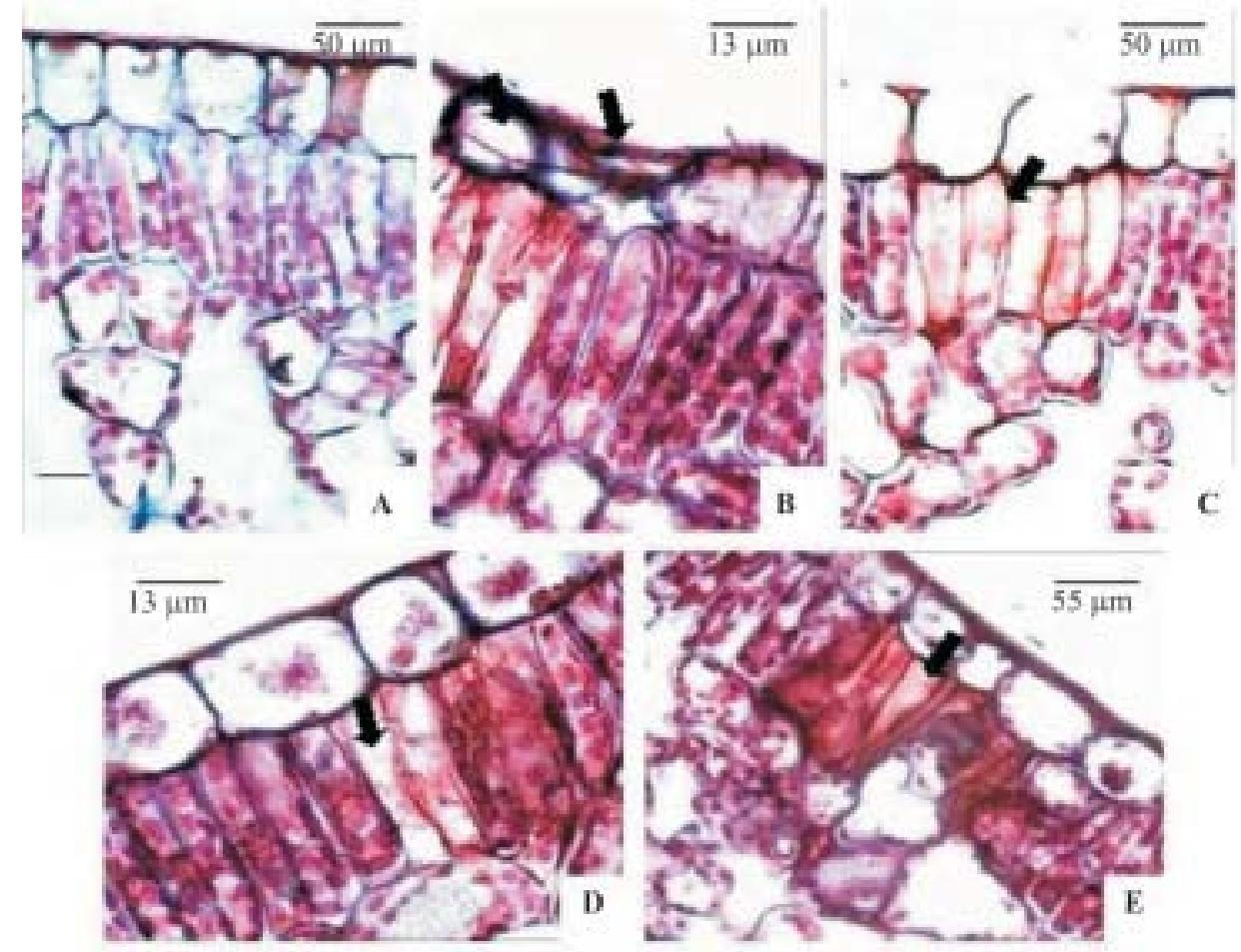

Figure 3. Transverse section of leaf blade of Coffea arabica 'Catuaî' infested by red mite: degree 1 (A); degree 2 (B, D); and degree $3(\mathbf{C})$. Recuperated $C$. arabica 'Mundo Novo' plants that had presented a high degree of red mite infestation during the prior growing season (2004-2005) are also shown (E). Arrows indicate chlorotic areas in the palisade parenchyma (B-E) and damage to the adaxial epidermis caused by the red mite (B).

Table 1. Effect of different degrees of red mite (Oligonychus ilicis) infestation on net photosynthetic rate $(A)$, stomatal conductance $\left(g_{s}\right)$, transpiration $(E)$, and ethylene evolution in leaves of Coffea arabica 'Catuaí Vermelho', and extent of chlorotic areas in the palisade parenchyma in leaves of $C$. arabica 'Mundo Novo'. D1 = leaves apparently healthy; D2 $=$ moderate infestation; D3 = high infestation. Data are the mean of 20 replicates for the chlorotic area and 10 replicates for the other characteristics. Means followed by the same letter within a column do not differ significantly at $P>0.05$ (Tukey test).

\begin{tabular}{cccccc}
$\begin{array}{c}\text { Infestation } \\
\text { degree }\end{array}$ & $\begin{array}{c}A \\
\left(\mu \mathrm{mol} \mathrm{m}^{-2} \mathrm{~s}^{-1}\right)\end{array}$ & $\begin{array}{c}E \\
\left(\mathrm{mmol} \mathrm{m}^{-2} \mathrm{~s}^{-1}\right)\end{array}$ & $\begin{array}{c}g_{\mathrm{s}} \\
\left(\mathrm{mmol} \mathrm{m}^{-2} \mathrm{~s}^{-1}\right)\end{array}$ & $\begin{array}{c}\text { Ethylene } \\
\left(\mathrm{nmol} \mathrm{g}^{-1} \mathrm{FW} \mathrm{d}^{-1}\right)\end{array}$ & $\begin{array}{c}\text { Chlorotic areas } \\
(\%)\end{array}$ \\
\hline D1 & $3.36 \mathrm{a}$ & $0.364 \mathrm{a}$ & $7.32 \mathrm{a}$ & $0.132 \mathrm{a}$ & $1.4 \mathrm{c}$ \\
$\mathrm{D} 2$ & $2.99 \mathrm{ab}$ & $0.368 \mathrm{a}$ & $6.78 \mathrm{a}$ & $0.132 \mathrm{a}$ & $16.9 \mathrm{~b}$ \\
$\mathrm{D} 3$ & $2.18 \mathrm{~b}$ & $0.323 \mathrm{a}$ & $6.48 \mathrm{a}$ & $0.150 \mathrm{a}$ & $45.7 \mathrm{a}$ \\
\hline
\end{tabular}

The alterations observed in the epidermis for degrees 2 and 3 (Figure 3B), correspond externally to the alterations seen on the leaf surface (Figure 2). It was also observed that the mite does not rupture the epidermis during feeding, which could be translated into unaltered transpiration (see below). Baker and Connell (1963) observed that in soybean these mites not only reach the palisade parenchyma during feeding but also the spongy parenchyma, destroying the chloroplasts. Therefore, the damage to this annual crop is greater than that seen for coffee plants.

Although the leaves of 'Mundo Novo' (that received phytosanitary treatment in 2005) appeared to have recovered from infestation, as judged by the apparent external healthy aspect (Figure 1F), chloroplasts of the targeted cells did not regenerate, thus remaining 
destroyed (Figure 3E). The leaves of 'Mundo Novo' suffering infestation during the dry period of 2005 were still attached to the plagiotropic branches, together with the fruits, and new leaves sprouted later in the vegetative phase during the following wet period resulted in a healthy aspect of the crop.

Gas exchange and ethylene evolution: The photosynthetic rate declined only in leaves under intense attack by red mites, probably due to the destruction of chloroplasts in the affected cells of palisade parenchyma (Table 1, Figure 3). It should be noted that the attack by red mites takes place mainly in the dry winter months, when the leaves of the coffee plant exhibit low metabolic activity and reduced rate of vegetative development. During the cool, dry season the rate of leaf growth is considerably lower $\left(0.9 \mathrm{~cm}^{2}\right.$ per week $)$ than that observed during the hot, rainy season $\left(9.2 \mathrm{~cm}^{2}\right.$ per week) (Barros and Maestri, 1974; Barros et al., 1997). Furthermore, the sprouting of new leaves increases tremendously in the hot, rainy season (Barros and Maestri, 1974), when the red mite is easily washed off the crop by rains. The sprouting of new leaves and the recovery of leaves previously under mite attack cast doubts whether the decrease in photosynthesis during the dry period would affect production in the following year. In fact, the yields obtained with 'Mundo Novo' crop in the 2004-2005 and 2005-2006 growing seasons were, respectively, 60 and 85 bags $(60 \mathrm{~kg}$ ) per hectare of processed coffee (data not shown). Taken together, these informations are in accordance with Ferreira et al. (1981) who showed that the yield of the coffee plant is not harmed by mite infestation over the range from zero to an extremely high level.

In studies with other plant species, it has been suggested that infestation by some tetranychid mites can lead to increases in leaf transpiration, probably due to the rupture of the epidermis of the attacked cells, resulting in drying-out and premature abscission of the leaves (Baker and Cornnel, 1963; Flechtmann, 1979). Such behaviour was not observed for coffee leaves infested by the red mite. The non-significant differences in transpiration rates among the treatments (Table 1) were probably due to the feeding habits of the mites which cause little damage to the epidermis.

It has been reported that an intensive red mite attack could cause leaf fall, thus impairing the coffee crop.
Nevertheless, there is no experimental data to support this allegation. Our data on ethylene production, which did not differ significantly among leaves at the three levels of mite infestation (Table 1), as well as the fact that leaves of 'Mundo Novo' plants showing external recovery in 2006 continued attached to the plant, argue against a mite infestation-induced leaf abscission. These data support the previous findings of Ferreira et al. (1981) who showed that different degrees of red mite infestation, from practically nil (two live mites per 30 leaves) to extremely high degrees (1033 mites per 30 leaves), did not correlate with leaf fall in coffee plants. For leaf abscission to occur the amount of ethylene produced by the leaf needs to increase considerably (Taiz and Zeiger, 1998). In addition, the probability of leaf abscission to take place in response to mechanical wounding may depend on the developmental stage of the affected tissue, immature leaves being more prone to abscise than mature leaves (Blundell and Peart, 2000; Kostenyuk and Burns, 2004). This may well be associated with more lignin and other secondary metabolites in mature than in immature leaves which in turn would help the former to be better protected against plagues and pathogens. It should be emphasised that the red mite attacks the coffee plant during the dry, cool period, when the growth rate is considerably reduced and only mature leaves are attached to the branches, which might at least partially explain why only little structural damage to the leaves was herein observed. This fact could contribute to the maintenance of leaf area regardless of mite attack. As a consequence, little, if any, decreases in crop yield are to be expected.

\section{REFERENCES}

Amaral JF (1951) O ácaro dos cafezais. Bol. Superintend. Serv. Café 26:846-848.

Baker JE, Connell WA (1963) The morphology of the mouthparts of Tetranychus atlanticus and observations on feeding by this mite on soybeans. Ann. Entomol. Soc. Am. 56:733-736.

Blundell AG, Peart DR (2000) High abscission rates of damaged expanding leaves: field evidence from seedlings of a Bornean rain forest tree. Am. J. Bot. 87:1693-1698.

Barros RS, Maestri M (1974) Influência dos fatores climáticos sobre a periodicidade de crescimento vegetativo do café (Coffea arabica L). Rev. Ceres 21:44-52. 
Barros RS, Mota JWS, DaMatta FM, Maestri M (1997) Decline of vegetative growth in Coffea arabica L. in relation to leaf temperature, water potential and stomatal conductance. Field Crops Res. 54:65-72.

Brown KE (1997) Ethylene and abscission. Physiol. Plant. 100:567-576.

Carvalho LM; Silva EAM, Azevedo AA, Mosquim PR, Cecon PR (2001) Aspectos morfofisiológicos das cultivares de cafeeiro Catuaí Vermelho e Conilon. Pesq. Agropec. Bras. 36:411-416.

Cheong YH, Chang HS, Grupta R, Wang Zhu T, Luan S (2002) Transcriptional profiling reveals novel interactions between wounding, pathogen, abiotic stress, and hormonal responses in Arabidopsis. Plant Physiol. 129:661-677.

Dedecca DM (1957) Anatomia e desenvolvimento ontogenético de Coffea arabica L. var. typica Cramer. Bragantia 16:315-366.

Ferreira AJ, Paulini AE, D’Antonio AM, Guimarães PM, Paula V (1980) Misturas de piretróides sintéticos com acaricidas e inseticidas acaricidas com a finalidade de controle simultâneo de bicho-mineiro - Perileucoptera coffeela (Guer.-Men.,1842) e ácaro vermelho Oligonychus ilicis (McGregor, 1919). In: Abstract of the VIII Congresso Brasileiro de Pesquisas Cafeeiras. Campos do Jordão, Brasil, pp.25-29.

Ferreira AJ, Matiello JB, Paulini AE, D’Antonio AM (1981) Correlação entre níveis de ataque de ácaro vermelho Oligonychus ilicis (McGregor, 1919) e produção do cafeeiro. In: Abstract of the IX Congresso Brasileiro de Pesquisas Cafeeiras. São Lourenço, Brasil, pp.230-231.

Flechtmann CHW (1979) Ácaros de Importância Agrícola. Livraria Nobel, São Paulo.

Gabrielli AC (1992) Contribuição ao estudo anatômico da raiz de Pyrostegia venusta (Ker) Miers-Bignoniaceae. Rev. Bras. Bot. 15:95-104.

Huffaker CB, Vrie M, McMurtry JA (1969) The ecology of tetranychid mites and their natural control. Annu. Rev. Entomol. 14:125-174.
Johansen DA (1940) Plant Microtechnique. McGraw-Hill, New York.

Kostenyuk IA, Burns LK (2004) Mechanical wounding and abscission in citrus. Physiol. Plant. 122:354-361.

Morais H, Medri ME, Marur CJ, Caramori PH, Ribeiro AMA, Gomes JC (2004) Modifications on leaf anatomy of Coffea arabica caused by shade of Pigeonpea (Cajanus cajan). Braz. Arch. Biol. Technol. 47:863-871.

Paulini AE, D’ Antonio AM, Matiello JB (1980) Efeito de inseticidas e acaricidas sobre a população do ácarovermelho Oligonychus ilicis (McGregor, 1919). In: Abstract of the VIII Congresso Brasileiro de Pesquisas Cafeeiras. Campos de Jordão, Brasil, pp.299-301.

Paulini AE, Miguel AE, Mansk Z (1975) Efeito de fungicida sobre o aumento da população do ácaro-vermelho Oligonychus ilicis (McGregor, 1919) em cafeeiros. In: Abstract of the III Congresso Brasileiro de Pesquisas Cafeeiras. Curitiba, Brasil, pp.38-40.

Reis PR, Souza JC (1986) Pragas do cafeeiro. In: Rena AB, Malavolta E, Rocha M, Yamada T (eds), Cultura do Cafeeiro: Fatores que Afetam a Produtividade, pp.323378. POTAFOS, Piracicaba.

Reis PR, Teodoro AV (2000) Efeito do oxicloreto de cobre sobre a reprodução do ácaro-vermelho do cafeeiro, Oligonychus ilicis (McGregor, 1919). Ciênc. Agrotec. 24:347-352.

Reis PR, Pedro Neto M, Franco RA, Teodoro AV (2004) Controle de Brevipalpus phoenicis (Geijskes, 1939) e Oligonychus ilicis (McGregor, 1917) (Acari: Tenuipalpidae, Tetranychidae) em cafeeiro e o impacto sobre ácaros benéficos. 1. Abamectin e Emacetin. Ciênc. Agrotec. 28:269-281.

Taiz L, Zeiger E (1998) Plant Physiology, $2^{\text {nd }}$ ed. Sinauer, Sunderland.

Voltan RBQ, Fahl JI, Carelli MLC (1992) Variação na anatomia foliar de cafeeiros submetidos a diferentes intensidades luminosas. Rev. Bras. Fisiol. Veg. 4:99-105.

Wang KL-C, Li H, Ecker JR (2002) Ethylene biosynthesis and signaling networks. Plant Cell 14:S131-S151. 